\title{
Synthesis of Nickel Nanoparticles Supported on Carbon Using a Filter Paper as Biomorphic Pattern for Application in Catalysis
}

\author{
Agustin Esteban Galetti ${ }^{a *}$, Mariana Noelia Barroso ${ }^{a}$, Antonio Monzón ${ }^{b}$, María Cristina Abello $^{a}$ \\ ${ }^{a}$ Instituto de Investigaciones en Tecnología Química - INTEQUI, Universidad Nacional de San Luis - \\ UNSL, Consejo Nacional de Investigaciones Cientificas y Técnicas - CONICET, \\ Chacabuco y Pedernera, San Luis, CP5700, Argentina \\ ${ }^{b}$ Departamento de Ingeniería Química y Tecnologías del Medio Ambiente, Instituto de Nanociencia de \\ Aragón, Universidad de Zaragoza, 50009, Zaragoza, España
}

Received: August 4, 2015; Revised: October 1, 2015

\begin{abstract}
Nickel catalysts supported over an amorphous carbon were obtained by a one-step synthesis method based on the mineralization of cellulosic paper impregnated with a salt of nickel. The effect of the mineralization temperature on material characteristics was studied. The characterization of samples revealed the formation of nickel nanoparticles well dispersed on the carbonaceous matrix with an average diameter near to $5 \mathrm{~nm}$. The samples showed high surface areas and they retained the original fibrous paper morphology.
\end{abstract}

Keywords: Ni nanoparticles, $N i-C$ catalysts, biomorphic catalysts

\section{Introduction}

In the recent years, the scientific community has focused on the development of materials in nanometric scale due to their unique properties and their potential application. Nickel nanoparticles have found application in the field of electronics, magnetism, energy, technology and biomedicine ${ }^{1}$.

Natural materials such as wood, cotton, bamboo, diatom, protein, agaroses, sponges, DNA, etc. have been employed as templates to synthesize biomorphic materials, in which the morphologies of the templates and hierarchical pore structure from millimeter to nanometer are well replicated ${ }^{2-7}$. This technology offers the possibility to use a wide variety of materials to produce microcellular ceramic, composites and nanocomposites ${ }^{8}$. The biomorphic templates have been applied to the synthesis of catalysts for several applications such as combustion of methane ${ }^{9}, \mathrm{CO}$ oxidation ${ }^{10}$ and hydrogen production ${ }^{11}$. Biomorphic templating has been applied in the synthesis of catalysts managed to produce materials that retain high surface areas after an extended treatment at elevated temperatures ${ }^{12}$.

Nickel is an attractive catalytic active phase for the reforming of hydrocarbons and biomass for hydrogen production $^{13-17}$ and also for hydrogenation in a liquid phase ${ }^{18}$ because of its optimal cost/activity rate compared with the noble metals. The main disadvantage is the tendency to deactivation by carbon deposition. Nickel particle size and its interaction with catalytic supports are key parameters for the control of the activity and carbon deposition rate.

Different types of carbon have been used as catalytic support for their high stability, simplicity for metal recovery and versatility to adjust superficial properties ${ }^{19,20}$. Carbon as support is also attractive for CNF production ${ }^{21,22}$. However, reaching a desired metal loading and a high dispersion level

*e-mail: agugaletti@yahoo.com.ar require superficial treatments on the C-support to ensure anchoring points for the metal ions adsorption ${ }^{19}$. Wang $\& \mathrm{Lu}^{23}$ have shown on activated carbon supported $\mathrm{Ni}$ catalysts that the amount of Ni adsorbed strongly depends on the severity of the acid pre-treatment given to the support.

In this work, a very simple and fast method to prepare $\mathrm{Ni}$ nanoparticles supported on carbon is described. The carbon was obtained from a filter paper which acts as: i) a porous medium able to absorb nickel solution and keep spaced $\mathrm{Ni}$ ions, ii) a carbon source for mineralization and iii) a biomorphic template. The influence of mineralization temperature on the some physico-chemical properties was studied. BET analysis, Scanning electron microscopy, Transmission electron microscopy, Raman spectroscopy, $\mathrm{X}$-ray diffraction and Thermogravimetry were employed to characterize the samples.

\section{Experimental}

\subsection{Sample preparation}

The raw material used as biomorphic template was discs of filter paper $\left(589^{2}\right.$, white ribbon, $125 \mathrm{~mm}$ diameter, SCHLEICHER \& SCHUELL CO.). Discs without any treatment were impregnated for 30 seconds in an aqueous solution of $\mathrm{Ni}\left(\mathrm{NO}_{3}\right)_{2} \cdot 6 \mathrm{H}_{2} \mathrm{O}$ (Sigma Aldrich) with a suitable concentration $\left(\mathrm{C}_{\mathrm{Ni}}\right)$ to reach a final loading of $7 \mathrm{wt} . \% \mathrm{Ni}$. Nickel concentration in the impregnation solution was calculated taking into account the paper liquid retention capacity (LRC) and the paper carbon yield (CY) at each mineralization temperature.

Wet hanged up paper discs were dried in static air at $80^{\circ} \mathrm{C}$ for 8 hours. Then they were mineralized under a flow of $5 \% \mathrm{H}_{2} / \mathrm{N}_{2}\left(300 \mathrm{~mL} \mathrm{~min}{ }^{-1}\right)$ in a tubular fixed bed reactor, from room temperature to $\mathrm{T}\left(\mathrm{T}=500,600\right.$ or $\left.700{ }^{\circ} \mathrm{C}\right)$ at 
a heating rate of $42{ }^{\circ} \mathrm{C} \mathrm{min}^{-1}$ following by an isothermal period at $\mathrm{T}$ for $30 \mathrm{~min}$. The samples were denominated $\mathrm{Ni}-\mathrm{C} 500, \mathrm{Ni}-\mathrm{C} 600$ and Ni-C700, respectively. Analogously, free-nickel samples obtained from mineralization of paper without any treatment were also prepared. These materials were denominated C500, C600 and C700.

The LRC value, $1.785 \mathrm{~g}_{\mathrm{H} 2 \mathrm{O}} \mathrm{g}_{\text {paper }}{ }^{-1}$, was determined by weight difference between wet paper and dry paper. The CY (Table 1) was calculated using the expression

$$
C Y(T)=\frac{w_{\text {carbon }}}{w_{\text {paper }}}
$$

where $w_{\text {PAPER }}$ is the weight in grams of filter paper loaded at the reactor and $w_{C A R B O N}$ the remaining weight in grams after carbonization at a given temperature $\mathrm{T}$.

\subsection{Characterization}

All samples were characterized using different physicochemical methods.

\subsubsection{BET surface area}

BET surface areas were measured by using a Micromeritics Gemini $\mathrm{V}$ analyzer by adsorption of nitrogen at $-196^{\circ} \mathrm{C}$ on $50 \mathrm{mg}$ of sample previously degassed at $300{ }^{\circ} \mathrm{C}$ for $16 \mathrm{~h}$ under flowing $\mathrm{N}_{2}$.

\subsubsection{X-Ray diffraction}

Diffraction patterns (XRD) were obtained with a RIGAKU diffractometer operated at $30 \mathrm{kV}$ and $20 \mathrm{~mA}$ by using Ni-filtered $\mathrm{Cu} \mathrm{Ka}$ radiation $(\lambda=0.15418 \mathrm{~nm})$ at a rate of $3^{\circ} \mathrm{min}^{-1}$ from $2 \theta=20$ to $80^{\circ}$. The identification of crystalline phases was made by matching with the JCPDS files. Ni particle size was estimated by the Scherrer equation using the peak centered at $2 \theta=44.35^{\circ}$.

\subsubsection{Thermal gravimetry}

The analyses were recorded using a DTG-50 Shimadzu equipment. The samples, ca. $8 \mathrm{mg}$, were placed in a Pt cell and heated from room temperature to $800{ }^{\circ} \mathrm{C}$ at a heating rate of $10{ }^{\circ} \mathrm{C} \mathrm{min}-1$ with a gas feed (air) of $50 \mathrm{~mL} \mathrm{~min}$. The Ni content, $\% \mathrm{Ni}$, was evaluated as:

$$
\% N i=\frac{w_{\text {nickel }}}{w_{\text {carbon }}+w_{\text {nickel }}} \times 100
$$

Where $w_{\text {NICKEL }}$ is the nickel weight calculated from the remaining weight after the TG analysis assuming all the residue is $\mathrm{NiO}$; and $w_{C A R B O N}$ is the carbon weight calculated from the weight loss measured by TGA.

\subsubsection{Raman spectroscopy}

The Raman spectra were recorded using a Lab Ram spectrometer (Jobin-Yvon) coupled to an Olympus confocal microscope (1009 objective lens were used for simultaneous illumination and collection) and equipped with a CCD with the detector cooled to about $-70{ }^{\circ} \mathrm{C}$ using the Peltier effect. The excitation wavelength was in all the cases $532 \mathrm{~nm}$ (Spectra Physics argon-ion laser). The laser power was set at $30 \mathrm{~mW}$. Integration times ranged from a few seconds to a few minutes depending on the sample.

\subsubsection{Transmission electron microscopy}

TEM micrographs images were recorded in a FEI Tecnai T20 equipment operated at $200 \mathrm{kV}$ so the irradiation damages were minimized. Specimens were prepared by standard techniques. TEM images allows to calculate the particle diameter $\bar{d}_{p}$ according to the suitable expression ${ }^{24}$

$\bar{d}_{p}=\frac{\sum n_{i} d_{i}^{3}}{\sum n_{i} d_{i}^{2}}$

\subsubsection{Scanning electron microscopy}

Scanning electron micrographs were obtained in a LEO 1450 VP. This instrument is equipped with an energy dispersive X-ray microanalyzer, EDAX Genesis 2000 with $\mathrm{Si}(\mathrm{Li})$ detector which permits analytical electron microscopy measurements. The samples were sputter coated with gold.

\section{Results and Discussion}

In Figure 1, the TG derivative curves of samples are presented. In all the cases, the decomposition temperature increases with temperature of mineralization, suggesting the presence of more stable carbonaceous species at higher temperature, according to literature reports ${ }^{25-27}$. The free-nickel samples C500 and C600, Figure 1a, show a slight gain of weight around 320 and $378^{\circ} \mathrm{C}$, respectively, which it is not observed in $\mathrm{C} 700$. This phenomenon could be associated at the oxidation of some organic compounds not completely eliminated in a reductive atmosphere at temperatures lower than $600{ }^{\circ} \mathrm{C}$ and it would be in agreement with the results of $\mathrm{S}_{\mathrm{BET}}$ further discussed. The final weight was nearly zero, indicating a very low ash content in the filter paper. In the samples with Ni, Figure 1b, the oxidation temperatures were lower than to the free-Ni samples. It would be associated to the nickel catalytic effect that favors the combustion of organic compounds. It is known that some transition metals

\begin{tabular}{|c|c|c|c|c|c|c|c|}
\hline Sample & wt. $\% \mathrm{Ni}^{(a)}$ & $\begin{array}{c}\mathrm{CY} \\
\mathbf{g}_{\text {carbon }} \mathbf{g}_{\text {paper }}^{-1} \\
\end{array}$ & $\begin{array}{c}\mathrm{C}_{\mathrm{Ni}} \\
\mathrm{g}_{\mathrm{Ni}} \mathbf{m L}^{-1}\end{array}$ & $\begin{array}{c}\mathrm{S}_{\text {BET }} \\
\mathbf{m}^{2} \mathbf{g}^{-1}\end{array}$ & $\begin{array}{c}\text { Pore diameter } \\
\mathbf{A}^{(\mathbf{b})} \\
\end{array}$ & $\begin{array}{c}\text { dXRDNi } \\
n^{(c)}\end{array}$ & $\mathbf{I}_{\mathbf{D}} / \mathbf{I}_{\mathrm{G}}$ \\
\hline $\mathrm{C} 500$ & -- & 0.165 & -- & 309 & -- & -- & -- \\
\hline C600 & -- & 0.122 & -- & 445 & -- & -- & -- \\
\hline C700 & -- & 0.135 & -- & 388 & -- & -- & -- \\
\hline $\mathrm{Ni}-\mathrm{C} 500$ & 7.2 & --- & $3.56 \times 10^{-2}$ & 396 & 39.8 & 5.3 & 0.66 \\
\hline Ni-C600 & 6.5 & --- & $2.63 \times 10^{-2}$ & 436 & 37.1 & 4.7 & 1.00 \\
\hline $\mathrm{Ni}-\mathrm{C} 700$ & 6.2 & --- & $2.91 \times 10^{-2}$ & 391 & 46.3 & 8.7 & 0.81 \\
\hline
\end{tabular}

Table 1. Some properties of Ni-C samples.

(a) from TGA data. ${ }^{\text {(b) }}$ BJH Desorption average pore width (4V/A). ${ }^{\text {(c) }}$ from XRD using Scherrer equation at $2 \theta=44.35^{\circ}$. 


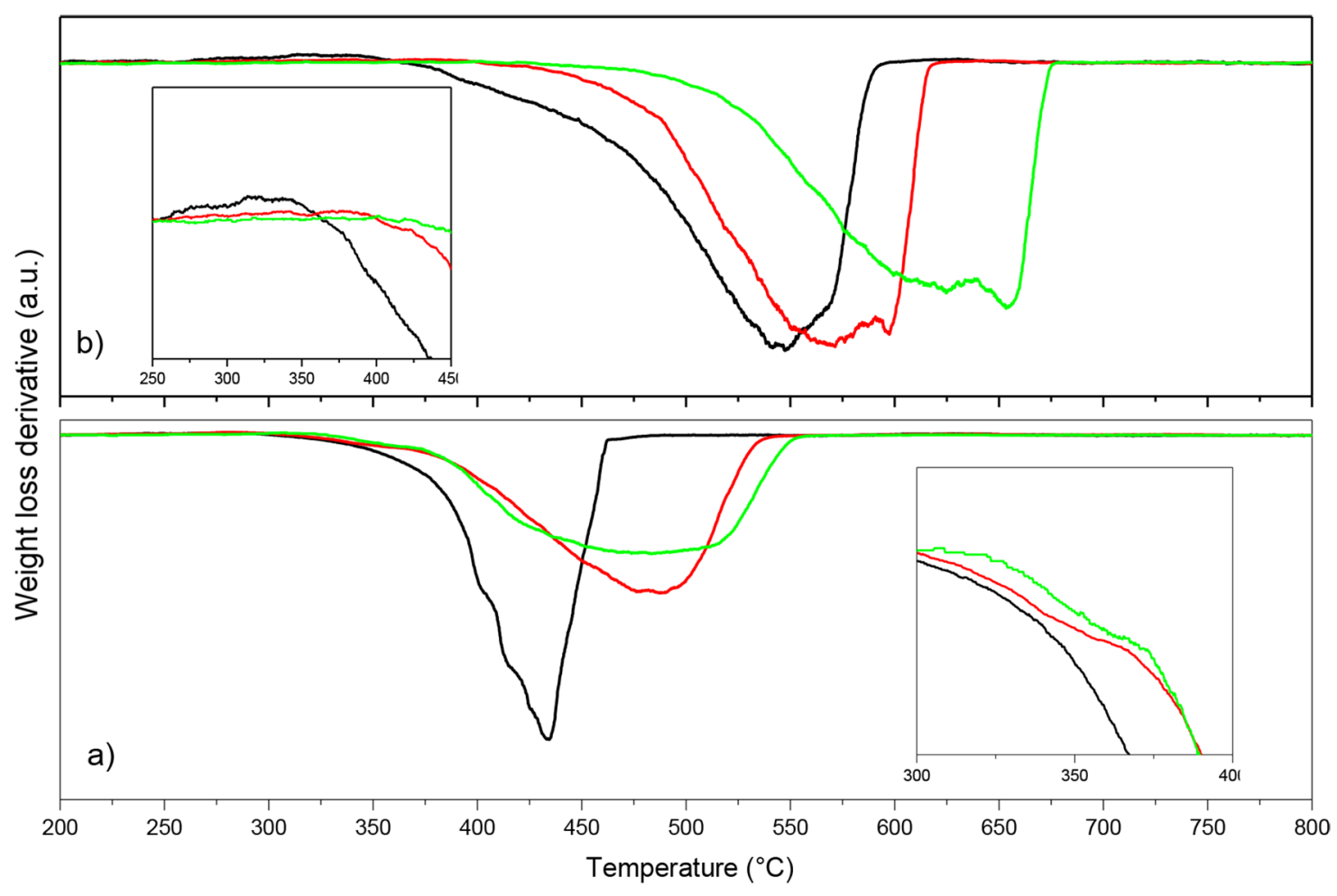

Figure 1. TG weight loss derivative of (a) free Ni samples: - C500, - C600, - C700; and (b) Ni-C samples: - Ni-C500, - Ni-C600, - Ni-C700.

such as $\mathrm{Ni}, \mathrm{Ru}, \mathrm{Rh}$, etc can catalyze the carbon gasification ${ }^{28}$. All samples present a slight increase of weight around $350{ }^{\circ} \mathrm{C}$ associated to the oxidation of $\mathrm{Ni}^{0}$. The total weight loss for each sample allows to estimate the Ni loading, being: 7.2, 6.5 and 6.2 wt.\% Ni for Ni-C500, Ni-C600 and Ni-C700, respectively, Table 1 . These values were close to the theoretical value validating the methodology applied for the calculus of $\mathrm{Ni}$ content in the impregnation solution.

The $\mathrm{N}_{2}$ adsorption-desorption isotherms (not shown) for all samples are type I according to the IUPAC classification with narrow type $\mathrm{H} 4$ hysteresis loops, similar to those other carbon materials. The specific surface areas, $\mathrm{S}_{\mathrm{BET}}$, are presented in Table 1. Although the mineralization temperature does not exhibit a strong effect on the specific surface, the $\mathrm{S}_{\mathrm{BET}}$ value for the sample calcined at $600^{\circ} \mathrm{C}$ with and without $\mathrm{Ni}$ reached the higher value. The increasing temperature up $600^{\circ} \mathrm{C}$ promotes the emptying of the pores in the carbonaceous matrix producing an increase in the BET surface. However, temperatures of mineralization higher than $600{ }^{\circ} \mathrm{C}$ would promote a structural collapse of the carbonaceous matrix leading to the decrease in the BET surface.

The XRD of Ni-C samples are shown in Figure 2. The Ni containing samples revealed the presence of amorphous carbon and $\mathrm{Ni}^{0}\left(2 \theta=44.5^{\circ}\right.$ and $\left.51.8^{\circ} \mathrm{JCPDS}-4-0850\right)$ even after air exposition at room temperature. Nickel particle sizes $\left(\mathrm{d}_{\mathrm{Ni}}\right)$ were estimated by Scherrer equation, Table 1. The Ni-C500 and Ni-C600 samples have a Ni particle size close to $5 \mathrm{~nm}$ while the sample obtained at $700{ }^{\circ} \mathrm{C}$ shows a slight higher value of $8.7 \mathrm{~nm}$, probably due to a sintering phenomenon during calcination at a higher temperature.

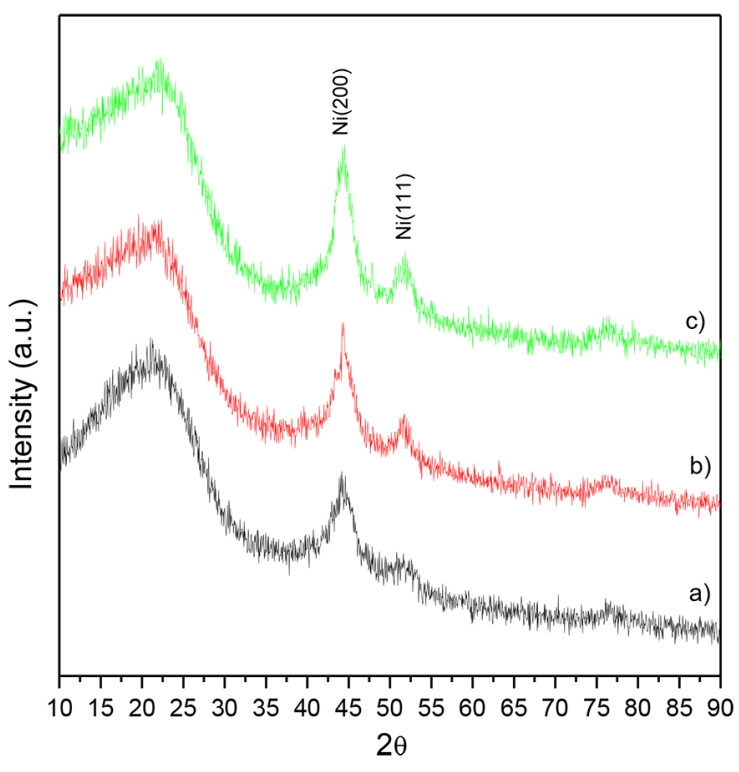

Figure 2. XRD of (a) Ni-C500; (b) Ni-C600 and (c) Ni-C700 samples.

The nature and characteristics of the carbonaceous species were also studied by Raman spectroscopy. In Figure 3, the Raman spectra of samples are shown in the range of $1100-1800 \mathrm{~cm}^{-1}$. In all the cases, two broad bands centered at $1579 \mathrm{~cm}^{-1}$ (G band) and $1344 \mathrm{~cm}^{-1}$ (D band) are observed. They are attributed to the stretching mode of carbon $\mathrm{sp}^{2}$ bonds of the typical graphite and to the vibrations of carbon atoms with dangling bonds in disordered graphite planes, respectively. 
Besides, the band at $1609 \mathrm{~cm}^{-1}$ known as $\mathrm{D}^{\prime}$ band is clearly observed when the mineralization temperature was $700^{\circ} \mathrm{C}$. This band is usually associated with defects which break the

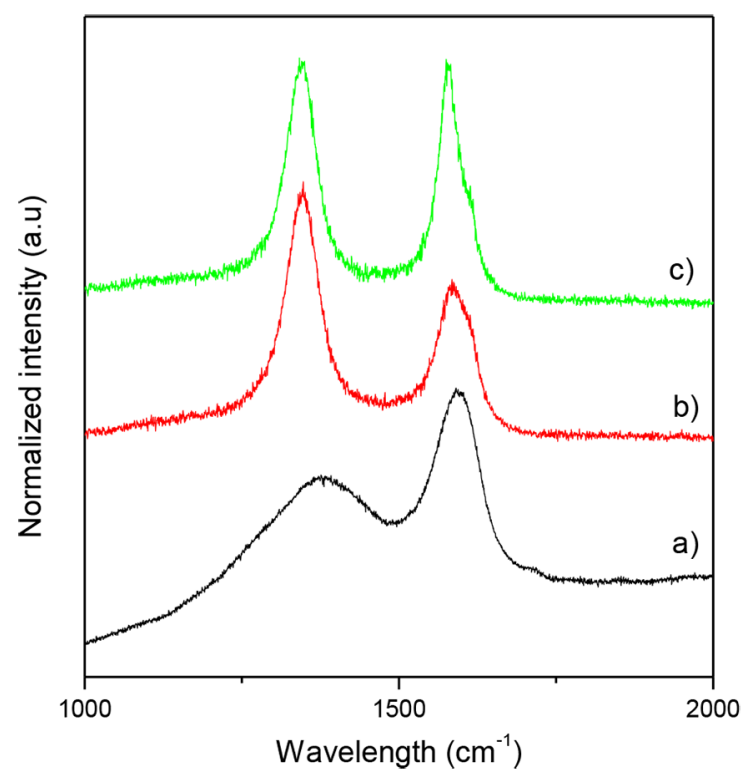

Figure 3. Raman spectra of (a) Ni-C500; (b) Ni-C600 and (c) Ni-C700 samples.

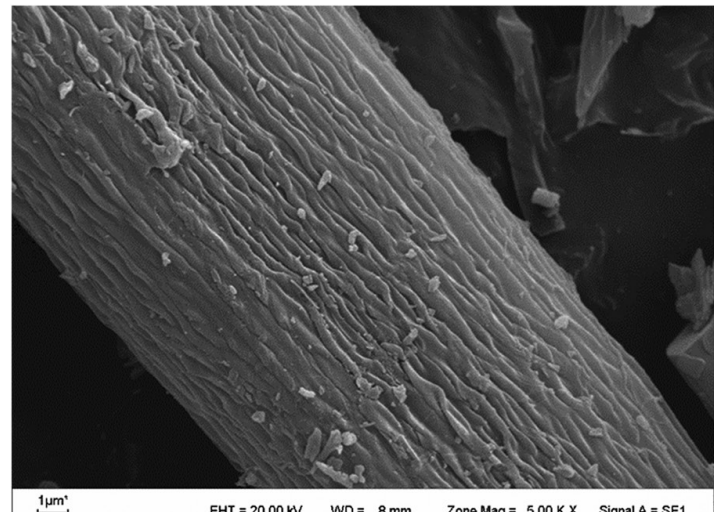

(a)

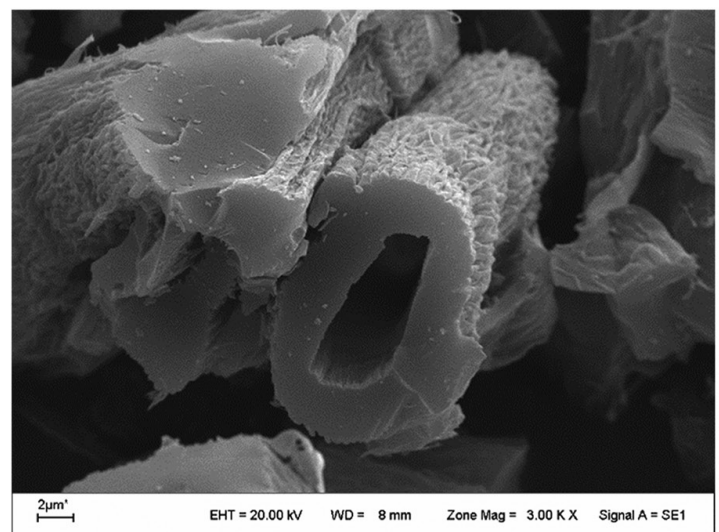

(c) translational symmetry of the graphene sheet. In general, it is assumed that when decreasing the D-to-G intensity ratio $\left(\mathrm{I}_{\mathrm{D}} / \mathrm{I}_{\mathrm{G}}\right)$, the degree of graphitization increases ${ }^{29}$. In Table 1, the $\mathrm{I}_{\mathrm{D}} / \mathrm{I}_{\mathrm{G}}$ intensity ratios are presented. Ni-C600 sample shows the lowest graphitization degree which might be related to the observed high BET surface.

The external structure of the samples was examined by scanning electron microscopy, Figure 4. Samples containing 7 wt. \% Ni (Figure 4a-c) exhibit similar structure to C700 free-Ni sample (Figure 4d). All the samples after the mineralization step preserve the biomorphic cellulose structure and hollow and non hollow microfibers with external diameter around 9-13 $\mu \mathrm{m}$ and internal diameter between 2-5 $\mu \mathrm{m}$ are detected, in agreement with the literature ${ }^{8}$.

TEM images of samples are presented in Figure 5. Nickel nanoparticles homogenously dispersed within the carbonaceous matrix are observed. The diameters close to $5 \mathrm{~nm}$ were determined on Ni-C500 and Ni-C600. In the sample Ni-C700, Figure 5c, d, a low amount of particles with a diameter higher at $5 \mathrm{~nm}(10-50 \mathrm{~nm})$ can be seen, in agreement with XRD results. These particles as it was mentioned before could be formed by sintering at $700^{\circ} \mathrm{C}$. Some of these particles have been encapsulated with many layers of graphene, Figure $5 \mathrm{~d}$, and they would not be available as catalytic active sites.

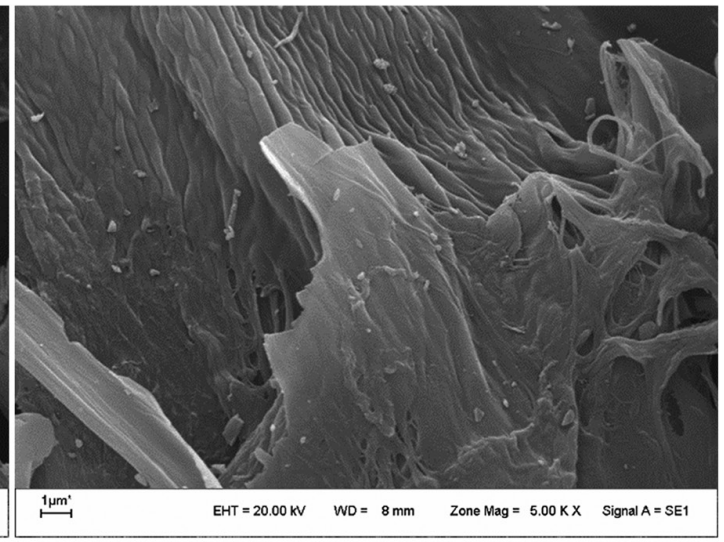

(b)

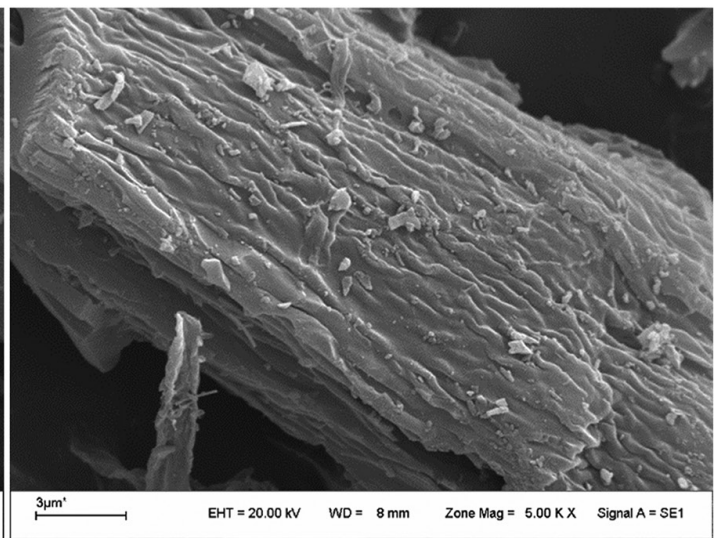

(d)

Figure 4. SEM images of (a) Ni-C500; (b) Ni-C600, (c) Ni-C700 and (d) C700 samples. 


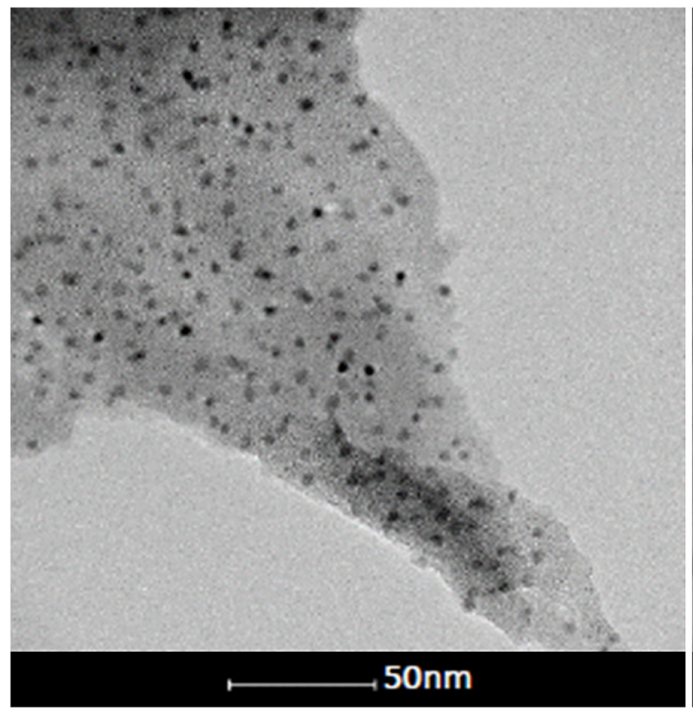

(a)

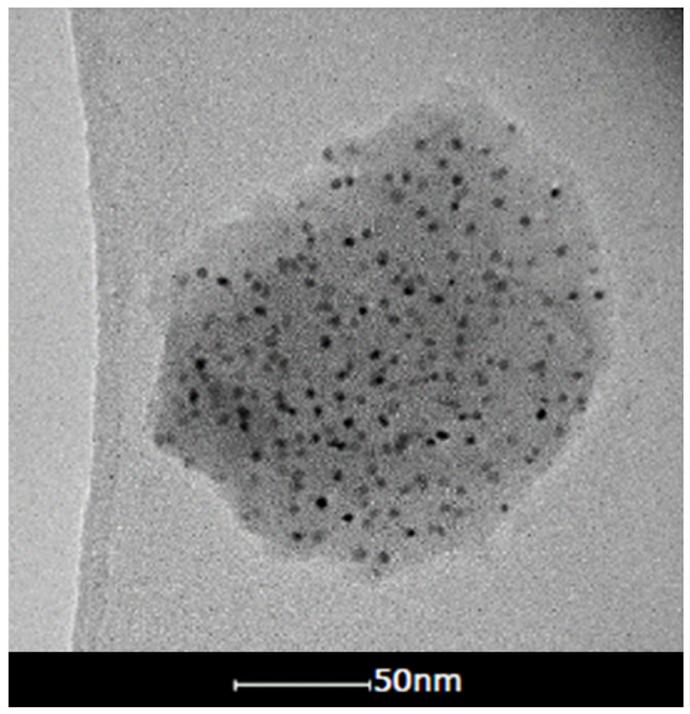

(c)

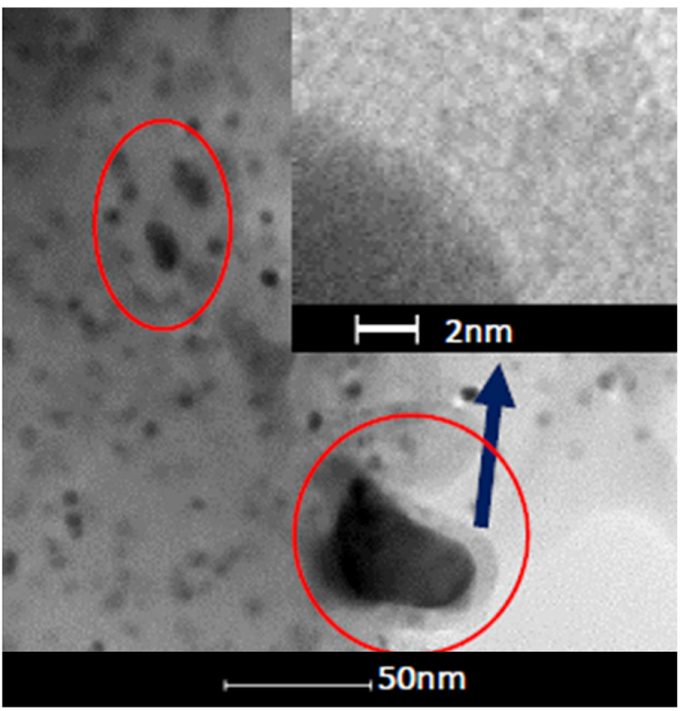

(b)

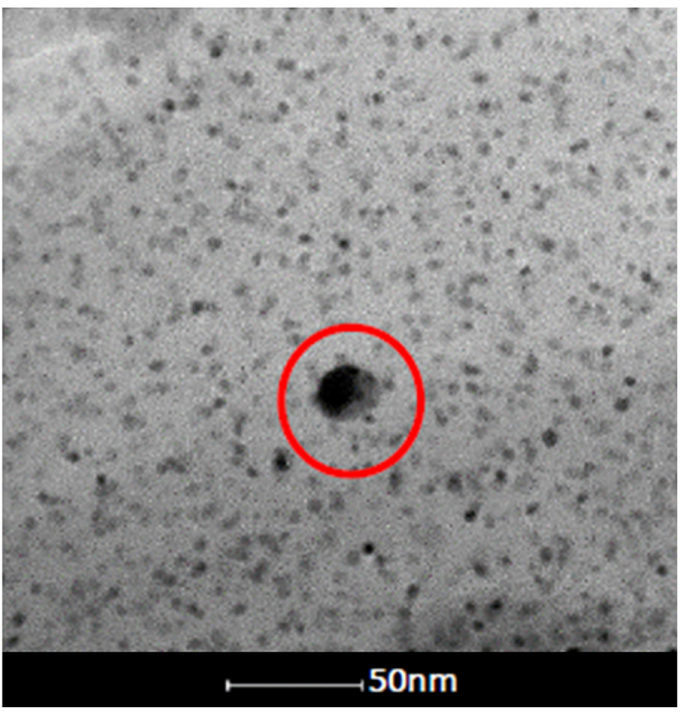

(d)

Figure 5. TEM micrographs of (a) Ni-C500; (b) Ni-C600; (c) and (d) Ni-C700 samples.

According to the results of the present work, the synthesis method used for preparation of $\mathrm{Ni}-\mathrm{C}$ catalysts was very simple and fast, without previous treatments of the support. The synthesized samples retained the original fibrous paper morphology. The optimum mineralization temperature for obtaining a homogeneous Ni distribution with particle sizes of $5 \mathrm{~nm}$ and to prevent sintering seems to be $600^{\circ} \mathrm{C}$.

\section{Conclusions}

A simple one step method to produce nickel nanoparticles over a carbon matrix has been developed. Cellulose filter papers as a carbon source were impregnated with a nickel aqueous solution as metal source. The impregnated filter papers were calcined in a reductive atmosphere at the temperature range of $500-700^{\circ} \mathrm{C}$. Nickel nanoparticles highly dispersed over a biomorphic carbonaceous structure with diameter close to $5 \mathrm{~nm}$ were obtained. The optimum mineralization temperature for obtaining a homogeneous $\mathrm{Ni}$ distribution and to prevent sintering seems to be $600^{\circ} \mathrm{C}$

This method of synthesis could be applied to other metals sources, either noble or non-noble, producing nanoparticled materials replacing currently multi-step preparation techniques. In addition, new materials could be developed being usefull in several fields like hydrogen storage, functionalized coatings, fuel cells electrodes, carbon nanotubes production and fine chemicals.

\section{Acknowledgements}

Financial supports are acknowledged to CONICET and Universidad Nacional de San Luis. The authors are grateful to Lic. Esther Fixman by the determination of $\mathrm{N}_{2}$ adsorption- desorption isotherms. The funds from the ANPCyT to buy the Raman instrument are also grateful (PME 87-PAE 36985). 


\section{References}

1. Alonso F, Riente P, Sirvent JA and Yus M. Nickel nanoparticles in hydrogen-transfer reductions: characterisation and nature of the catalyst. Applied Catalysis A, General. 2010; 378(1):42-51. http://dx.doi.org/10.1016/j.apcata.2010.01.044.

2. Zhu S, Zhang D, Li Z, Furukawa $\mathrm{H}$ and Chen Z. Precision replication of hierarchical biological structures by metal oxides using a sonochemical method. Langmuir. 2008; 24(12):6292-6299. http://dx.doi.org/10.1021/la7037153. PMid:18489191.

3. Fan T-X, Chow S-K and Zhang D. Biomorphic mineralization: from biology to materials. Progress in Materials Science. 2009; 54(5):542-659. http://dx.doi.org/10.1016/j.pmatsci.2009.02.001.

4. Fabritius H-O, Sasch C, Triguero PR and Raabe D. Influence of structural principles on the mechanics of a biological fiberbased composite material with hierarchical organization: the exoskeleton of the lobster homarus americanus. Advanced Materials. 2009; 21(4):391-400. http://dx.doi.org/10.1002/ adma.200801219.

5. Sapei L, Nöske R, Strauch P and Paris O. Isolation of mesoporous biogenic silica from the perennial plant Equisetum hyemale. Chemistry of Materials. 2008; 20(5):2020-2025. http://dx.doi. org/10.1021/cm702991f.

6. Bai B, Wang $\mathrm{P}$, Wu L, Yang $\mathrm{L}$ and Chen $\mathrm{Z}$. A novel yeast bio-template route to synthesize $\mathrm{Cr}_{2} \mathrm{O}_{3}$ hollow microspheres. Materials Chemistry and Physics. 2009; 114(1):26-29. http:// dx.doi.org/10.1016/j.matchemphys.2008.10.030.

7. Yuan RS, Fu XZ, Wang XC, Liu P, Wu L, Xu YM, et al. Template synthesis of hollow metal oxide fibers with hierarchical architecture. Chemistry of Materials. 2006; 18(19):4700-4705. http://dx.doi.org/10.1021/cm0609911.

8. Zuo C, Li Q, Peng G and Xing G. Manufacture of biomorphic $\mathrm{Al}_{2} \mathrm{O}_{3}$ ceramics using filter paper as template. rogress in Natural Science: Materials International. 2011;21(6):455-459. http:// dx.doi.org/10.1016/S1002-0071(12)60082-3.

9. Luo J, Xu H, Liu Y, Chu W, Jiang C and Zhao X. A facile approach for the preparation of biomorphic $\mathrm{CuO}-\mathrm{ZrO}_{2}$ catalyst for catalytic combustion of methane. Applied Catalysis A, General. 2012; 423-424:121-129. http://dx.doi.org/10.1016/j. apcata.2012.02.025.

10. Chiu K, Kwong F-L and Ng DHL. Enhanced oxidation of CO by using a porous biomorphic $\mathrm{CuO} / \mathrm{CeO}_{2} / \mathrm{Al}_{2} \mathrm{O}_{3}$ compound. Microporous and Mesoporous Materials. 2012;156:1-6. http:// dx.doi.org/10.1016/j.micromeso.2012.02.015.

11. Church TL, Fallani S, Liu J, Zhao M and Harris AT. Document novel biomorphic $\mathrm{Ni} / \mathrm{SiC}$ catalysts that enhance cellulose conversion to hydrogen. Catalysis Today. 2012; 190(1):98-106. http://dx.doi.org/10.1016/j.cattod.2012.01.041.

12. Shigapova AN, Grahamb GW, McCabeb RW and Plummer HK Jr. The preparation of high-surface area, thermally-stable, metal-oxide catalysts and supports by a cellulose templating approach. Applied Catalysis A, General. 2001;210(1-2):287-300. http://dx.doi.org/10.1016/S0926-860X(00)00820-6.

13. Galetti A, Gomez M, Arrua L and Abello MC. Ni catalysts supported on modified $\mathrm{ZnAl}_{2} \mathrm{O}_{4}$ for ethanol steam reforming. Applied Catalysis A, General. 2010; 380(1-2):40-47. http:// dx.doi.org/10.1016/j.apcata.2010.03.024.

14. Comas J, Mariño F, Laborde M and Amadeo N. Bio-ethanol steam reforming on $\mathrm{Ni} / \mathrm{Al}_{2} \mathrm{O}_{3}$ catalyst. Chemical Engineering Journal. 2004; 98(1-2):61-68. http://dx.doi.org/10.1016/S13858947(03)00186-4.

15. Barroso M, Galetti A, Gomez M, Arrúa L and Abello MC. $\mathrm{Ni}$-catalysts supported on $\mathrm{Zn}_{\mathrm{x}} \mathrm{Mg}_{1-\mathrm{x}} \mathrm{Al}_{2} \mathrm{O}_{4}$ for ethanol steam reforming: influence of the substitution for $\mathrm{Mg}$ on catalytic activity and stability. Chemical Engineering Journal. 2013; 222:142-149. http://dx.doi.org/10.1016/j.cej.2013.02.051.

16. Mas V, Baronetti G, Amadeo N and Laborde M. Ethanol steam reforming using $\mathrm{Ni}(\mathrm{II})-\mathrm{Al}(\mathrm{III})$ layered double hydroxide as catalyst precursor: Kinetic study. Chemical Engineering Journal. 2008; 138(1-3):602-607. http://dx.doi.org/10.1016/j. cej.2007.08.035.

17. Galetti A, Barroso N, Gomez M, Arrua L, Monzón A and Abello MC. Promotion of $\mathrm{Ni} / \mathrm{MgAl}_{2} \mathrm{O}_{4}$ catalysts with rare earths for the ethanol steam reforming reaction. Catalysis Letters. 2012; 142(12):1461-1469. http://dx.doi.org/10.1007/s10562-0120927-9.

18. Trasarti A, Bertero N, Apesteguia C and Marchi AJ. Liquid-phase hydrogenation of acetophenone over silica-supported $\mathrm{Ni}$, Co and $\mathrm{Cu}$ catalysts: influence of metal and solvent. Applied Catalysis A, General. 2014; 475:282-291. http://dx.doi.org/10.1016/j. apcata.2014.01.038.

19. Silva LMS, Órfão JJM and Figueiredo JL. Formation of two metal phases in the preparation of activated carbon-supported nickel catalysts. Applied Catalysis A, General. 2001; 209 (1-2):145-154. http://dx.doi.org/10.1016/S0926-860X(00)00762-6.

20. Rodriguez-Reinoso F. The role of carbon materials in heterogeneous catalysis. Carbon. 1998; 36(3):159-175. http:// dx.doi.org/10.1016/S0008-6223(97)00173-5.

21. Auer E, Freund A, Pietsch J and Tacke T. Carbons as supports for industrial precious metal catalysts. Applied Catalysis A, General. 1998; 173(2):259-271. http://dx.doi.org/10.1016/ S0926-860X(98)00184-7.

22. Otsuka K, Ogihara H and Takenaka S. Decomposition of methane over Ni catalysts supported on carbon fibers formed from different hydrocarbons. Carbon. 2003; 41(2):223-233. http://dx.doi.org/10.1016/S0008-6223(02)00308-1.

23. Wang S and (Max)Lu GQ. Effects of acidic treatments on the pore and surface properties of ni catalyst supported on activated carbon. Carbon. 1998; 36:283-292. http://dx.doi.org/10.1016/ S0008-6223(97)00187-5.

24. Ertl G, Knözinger H, Weitkamp J, editors. Handbook of heterogeneous catalysis. Weinheim: Wiley-VCH; 1997. v. 3. $738 \mathrm{p}$.

25. Sánchez-Sánchez MC, Navarro RM and Fierro JLG. Ethanol steam reforming over $\mathrm{Ni} / \mathrm{M}_{\mathrm{x}} \mathrm{O}_{\mathrm{y}}-\mathrm{Al}_{2} \mathrm{O}_{3}(=\mathrm{Ce}, \mathrm{La}, \mathrm{Zr}$ and $\mathrm{Mg}$ ) catalysts: influence of support on the hydrogen production. International Journal of Hydrogen Energy. 2007; 32(10-11):1462-1471. http://dx.doi.org/10.1016/j.ijhydene.2006.10.025.

26. Guo J, Lou H, Zhao H, Chai D and Zheng X. Dry reforming of methane over nickel catalysts supported on magnesium aluminate spinels. Applied Catalysis A, General. 2004; 273(1-2):75-82. http://dx.doi.org/10.1016/j.apcata.2004.06.014.

27. Barroso MN, Galetti AE and Abello MC. Ni catalysts supported over $\mathrm{MgAl}_{2} \mathrm{O}_{4}$ modified with $\mathrm{Pr}$ for hydrogen production from ethanol steam reforming. Applied Catalysis A, General. 2011; 394(1-2):124-131. http://dx.doi.org/10.1016/j.apcata.2010.12.038.

28. Tamai $Y$, Watanabe $H$ and Tomita A. Catalytic gasification of carbon with steam, carbon dioxide and hydrogen. Carbon. 1977; 15(2):103-106. http://dx.doi.org/10.1016/0008-6223(77)900240 .

29. Bobadilla LF, Álvarez A, Domínguez MI, Romero-Sarria F, Centeno MA, Montes M, et al. Influence of the shape of $\mathrm{Ni}$ catalysts in the glycerol steam reforming. Applied Catalysis B: Environmental. 2012; 123:379-390. http://dx.doi.org/10.1016/j. apcatb.2012.05.004. 